Nevada

Environmental

Restoration

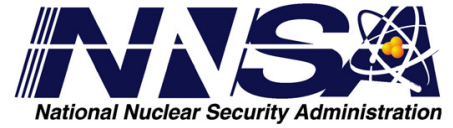

Project

\title{
Addendum to the Closure Report for Corrective Action Unit 262: \\ Area 25 Septic Systems and \\ Underground Discharge Point, \\ Nevada Test Site, Nevada
}

Controlled Copy No.:

Revision No.: 0

October 2008

Approved for public release; further dissemination unlimited.

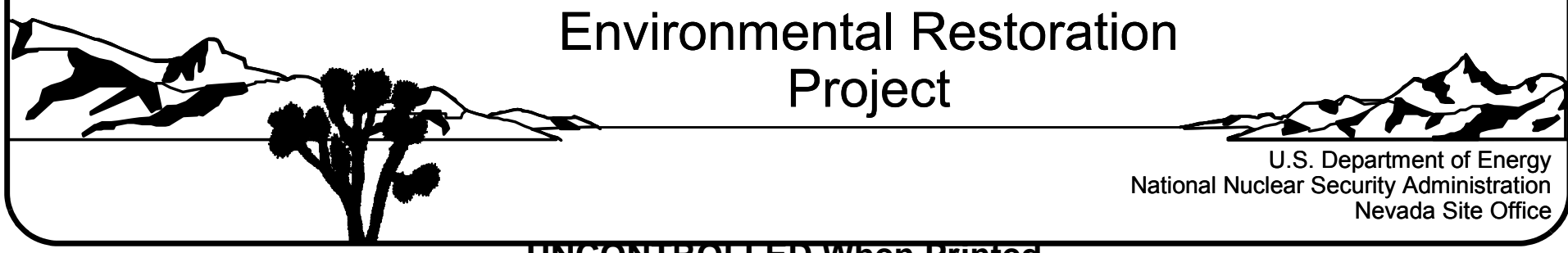


Available for public sale, in paper, from:

U.S. Department of Commerce

National Technical Information Service

5285 Port Royal Road

Springfield, VA 22161

Phone: 800.553 .6847

Fax: 703.605.6900

Email: orders@ntis.gov

Online ordering: http://www.ntis.gov/ordering.htm

Available electronically at $\underline{h t p: / / w w w . o s t i . g o v / b r i d g e ~}$

Available for a processing fee to U.S. Department of Energy and its contractors, in paper, from:

U.S. Department of Energy

Office of Scientific and Technical Information

P.O. Box 62

Oak Ridge, TN 37831-0062

Phone: 865.576 .8401

Fax: 865.576.5728

Email: reports@adonis.osti.gov

Reference herein to any specific commercial product, process, or service by trade name, trademark, manufacturer, or otherwise, does not necessarily constitute or imply its endorsement, recommendation, or favoring by the United States Government or any agency thereof or its contractors or subcontractors. 


\title{
ADDENDUM TO THE CLOSURE REPORT FOR CORRECTIVE ACTION UNIT 262: AREA 25 SEPTIC SYSTEMS AND UNDERGROUND DISCHARGE POINT, NEVADA TEST SITE, NEVADA
}

\author{
U.S. Department of Energy \\ National Nuclear Security Administration \\ Nevada Site Office \\ Las Vegas, Nevada
}

Controlled Copy No.:

Revision No.: 0

October 2008

Approved for public release; further dissemination unlimited. 


\section{Addendum to the Closure Report for Removal of the Use Restriction}

This document constitutes an addendum to the July 2003, Closure Report for Corrective Action Unit 262: Area 25 Septic Systems and Underground Discharge Point as described in the document Recommendations and Justifications for Modifications for Use Restrictions Established under the U.S. Department of Energy, National Nuclear Security Administration Nevada Site Office Federal Facility Agreement and Consent Order (UR Modification document) dated February 2008. The UR Modification document was approved by NDEP on February 26, 2008. The approval of the UR Modification document constituted approval of each of the recommended UR modifications. In conformance with the UR Modification document, this addendum consists of:

- This cover page that refers the reader to the UR Modification document for additional information

- The cover and signature pages of the UR Modification document

- The NDEP approval letter

- The corresponding section of the UR Modification document

This addendum provides the documentation justifying the cancellation of the UR for CAS 25-05-06, Leachfield. This UR was established as part of a Federal Facility Agreement and Consent Order (FFACO) corrective action and is based on the presence of contaminants at concentrations greater than the action levels established at the time of the initial investigation (FFACO, 1996; as amended August 2006).

Since this UR was established, practices and procedures relating to the implementation of risk-based corrective actions (RBCA) have changed. Therefore, this UR was re-evaluated against the current RBCA criteria as defined in the Industrial Sites Project Establishment of Final Action Levels (NNSA/NSO, 2006c). This re-evaluation consisted of comparing the original data (used to define the need for the UR) to risk-based final action levels (FALs) developed using the current Industrial Sites RBCA process.

The re-evaluation resulted in a recommendation to remove the UR because contamination is not present at the site above the risk-based FALs. Requirements for inspecting and maintaining this UR will be canceled, and the postings and signage at this site will be removed. Fencing and posting may be present at this site that are unrelated to the FFACO UR such as for radiological control purposes as required by the $N V / Y M P$ Radiological Control Manual (NNSA/NSO, 2004f). This modification will not affect or modify any non-FFACO requirements for fencing, posting, or monitoring at this site. 
Nevada

Environmental

Restoration

Project

Recommendations and Justifications for Modifications for Use Restrictions Established under the U.S. Department of Energy, National Nuclear Security Administration Nevada Site Office

Federal Facility Agreement and Consent Order

Controlled Copy No.:

Revision No.: 0

February 2008

Approved for public release; further dissemination unlimited.

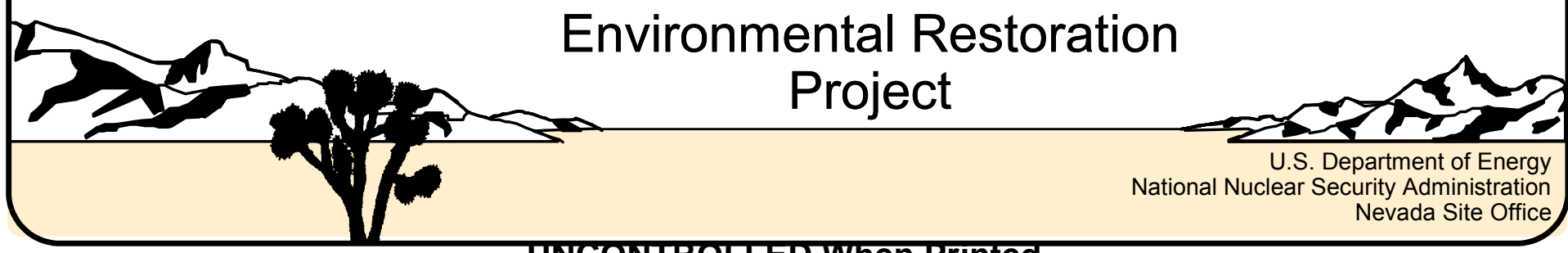


Recommendations and Justifications for Modifications for Use Restrictions Established under the U.S. Department of Energy, National Nuclear Security Administration Nevada Site Office Federal Facility Agreement and Consent Order

Approved by: /s/ Kevin J. Cabble

Date: $02 / 05 / 2008$

Kevin J. Cabble

Federal Sub-Project Director

Industrial Sites Sub-Project

Approved by:

/s/ John B. Jones

Date: $02 / 04 / 2008$

John B. Jones

Acting Federal Project Director

Environmental Restoration Project 
February 26, 2008

John B. Jones

Acting Federal Project Director

Environmental Restoration Project

National Nuclear Security Administration

Nevada Site Office

P. O. Box 98518

Las Vegas, NV 89193-8518

RE: Approval of Recommendations and Justifications for Modifications for Use Restrictions

Established under the U.S. Department of Energy, National Nuclear Security Administration, Nevada Site Office Federal Facility Agreement and Consent Order

Dear Mr. Jones:

The Nevada Division of Environmental Protection, Bureau of Federal Facilities (NDEP) staff has received and reviewed the February 2008 final report for Recommendations and Justifications for Modifications for Use Restrictions Established under the U.S. Department of Energy, National Nuclear Security Administration, Nevada Site Office. The NDEP approves the requested changes to the previously agreed upon use restrictions for those Corrective Action Sites (CASs) as described in the report.

Address any questions regarding this matter to either Ted Zaferatos at (702) 486-2850, ext. 234 , or me at (702) 486-2850, ext. 231.

Sincerely

\section{/s/ Tim Murphy}

\section{T.H. Murphy}

Chief

Bureau of Federal Facilities

$\mathrm{TZ}$

cc: $\quad$ E.F. DiSanza, WMP, NNSA/NSO

FFACO Group, PSG, NNSAINSO, Las Vegas, NV

David C. Loewer, DTRAVCXT1, M/S 645, Mercury, NV

W.R. Griffin, SNJV/DTRA, M/S 645, Mercury, NV

T.A. Thiele, NSTec, Las Vegas, NV

R.F. Boehlecke, SNJV, Las Vegas, NV

K. J. Cabble, ERP, NNSANSO, Las Vegas, NV

John Wong. Jeff MacDougall, Dennis Nicodemus, NDEP Las Vegas, NV 


\subsection{CAU 262, CAS 25-05-06 - Leachfield}

\subsection{CAS Description}

The Engine Maintenance, Assembly, and Disassembly (E-MAD) Facility Posted Leachfield System (CAS 25-05-06) received radioactive and process effluent from Building 3900 (E-MAD Building). The CAS consists of the leachfield, distribution box, and associated piping. The leachfield is located approximately $625 \mathrm{ft}$ southwest of Building 3900. Waste liquids generated by decontamination and chemical analysis of test units, and decontamination of personnel, equipment, and the facility were received by dedicated radioactive wastewater drains. The E-MAD Building, adjoining trailers, and the Train Decontamination Area pad components of the E-MAD Facility were connected to the posted leachfield through pipes or waste holdup tanks in a vault on the east side of the E-MAD Building (NNSA/NV, 2001a).

\subsection{Current Use Restriction Description}

The future use of any land related to this UR is restricted from any DOE or Air Force activity that may alter or modify the containment control, as approved by the state and identified in the CAU CR or other CAU documentation, unless appropriate concurrence is obtained in advance. The UR is defined by the 2.1-meter (m) (7-ft)-high security fence bounding the leachfield. An inspection will be performed annually and consist of visual observations to verify that the fence is in good condition, proper signs are in place and readable, and the UR is maintained (NNSA/NSO, 2003a).

\subsection{Basis for Current Use Restriction}

Samples from this CAS were analyzed for PCBs, total VOCs, total SVOCs, TPH Diesel/Oil, total RCRA metals, isotopic $\mathrm{Pu}$, isotopic $\mathrm{U}$, gamma spectroscopy, and Sr-90. Ten of 97 subsurface soil samples were contaminated with Sr-90 at concentrations exceeding the PAL. Of those 10 samples, two had cesium (Cs)-137 and U contamination exceeding PALs. The PALs for the radionuclides were established in the CAIP as any activity distinguishable from undisturbed background activity. No VOC, TPH, SVOC, or PCB analytical results exceeded PALs. All RCRA metals analytical results were below PALs, except arsenic, which was detected above the PAL of $2.7 \mathrm{mg} / \mathrm{kg}$ in 59 of the 94 samples. The concentrations of arsenic above the PAL of $2.7 \mathrm{mg} / \mathrm{kg}$ were within the range considered representative of ambient conditions at the site. Therefore, arsenic is not considered to be a basis for this UR (NNSA/NV, 2001a). 
Table 6-1 contains analytical results of all COCs at CAS 25-05-06 that are the basis for the current UR. The sample matrix for all samples is soil.

Table 6-1

Sample Results for COCs at CAS 25-05-06

Used To Establish Current Use Restriction

\begin{tabular}{|c|c|c|c|c|c|}
\hline \multirow{2}{*}{ Sample ID } & \multirow{2}{*}{$\begin{array}{l}\text { Depth } \\
\text { (ft bgs) }\end{array}$} & Cs-137 & U-234 & U-235 & Sr-90 \\
\hline & & $\begin{array}{c}\text { PAL } \\
7 \mathrm{pCi} / \mathrm{g}\end{array}$ & $\begin{array}{c}\text { PAL } \\
1.56 \mathrm{pCi} / \mathrm{g}\end{array}$ & $\begin{array}{c}\text { PAL } \\
0.07 \mathrm{pCi} / \mathrm{g}\end{array}$ & $\begin{array}{c}\text { PAL } \\
1.17 \mathrm{pCi} / \mathrm{g}\end{array}$ \\
\hline EPR02B06 & $6.5-7.5$ & -- & -- & -- & $1.77 \pm 0.40$ \\
\hline EPR03B13 & $13.5-14.5$ & -- & -- & $0.08 \pm 0.030$ & -- \\
\hline EPR04A06 & $6-7$ & $44.5 \pm 5.7$ & $8.5 \pm 1.1$ & $0.42 \pm 0.081$ & $12.6 \pm 2.3$ \\
\hline EPR04A08 & $8.5-9.5$ & -- & $1.69 \pm 0.24$ & $0.108 \pm 0.034$ & -- \\
\hline EPR05A14 & $14-15$ & -- & -- & $0.08 \pm 0.03$ & -- \\
\hline EPR05A24 & $24-25$ & -- & -- & $0.093 \pm 0.035$ & -- \\
\hline EPR11A10 & $10-11$ & -- & -- & $0.085 \pm 0.031$ & -- \\
\hline EPR12A07 & $7.5-8.5$ & -- & -- & $0.102 \pm 0.035$ & -- \\
\hline EPR12A10 & $10-11$ & -- & -- & $0.109 \pm 0.039$ & $3.42 \pm 0.69$ \\
\hline EPR13A08 & $8-9$ & -- & $2.03 \pm 0.30$ & $0.112 \pm 0.036$ & $8.9 \pm 1.6$ \\
\hline EPR13A10 & $10.5-11.5$ & -- & -- & $0.083 \pm 0.030$ & $3.62 \pm 0.72$ \\
\hline EPR13A20 & $20.5-21.5$ & -- & -- & $0.104 \pm 0.034$ & -- \\
\hline EPR13A99 & $10.5-11.5$ & -- & -- & $0.101 \pm 0.033$ & $3.09 \pm 0.62$ \\
\hline EPR14A07 & $7.5-8.5$ & -- & $1.61 \pm 0.30$ & $0.115 \pm 0.052(\mathrm{~J})$ & $3.70 \pm 0.71$ \\
\hline EPR15A07 & $7.5-8.5$ & -- & -- & $0.084 \pm 0.039(\mathrm{~J})$ & -- \\
\hline EPR16A07 & $7.5-8.5$ & -- & -- & $0.09 \pm 0.039(\mathrm{~J})$ & $2.63 \pm 0.53$ \\
\hline EPR17A07 & $7.5-8.5$ & $11.9 \pm 1.5$ & -- & -- & $4.82 \pm 0.92$ \\
\hline EPR17A10 & $10-11$ & -- & -- & $0.129 \pm 0.047$ & $3.03 \pm 0.61$ \\
\hline EPR18A07 & $7-8$ & -- & -- & $0.091 \pm 0.041$ & -- \\
\hline EPR18A09 & $9.5-10.5$ & -- & -- & $0.087 \pm 0.037$ & -- \\
\hline EPR19A07 & $7-8$ & -- & - & $0.087 \pm 0.041$ & -- \\
\hline EPR19A09 & $9.5-10.5$ & -- & -- & $0.073 \pm 0.036$ & -- \\
\hline EPR19A15 & $15-16$ & -- & - & $0.071 \pm 0.035$ & - \\
\hline EPR20A10 & $10-11$ & -- & - & $0.073 \pm 0.040$ & -- \\
\hline EPR21A09 & $9.5-10.5$ & - & -- & $0.081 \pm 0.041$ & -- \\
\hline EPR22A09 & $9.5-10.5$ & - & -- & $0.07 \pm 0.035$ & -- \\
\hline EPR29A20 & $20-21$ & -- & -- & $0.073 \pm 0.026$ & -- \\
\hline
\end{tabular}

bgs $=$ Below ground surface

$\mathrm{Cs}=$ Cesium

$\mathrm{ft}=$ Foot

ID = Identification

$\mathrm{J}=$ Estimated value

-- $=$ No detects above action levels
$\mathrm{PAL}=$ Preliminary action level $\mathrm{pCi} / \mathrm{g}=$ Picocuries per gram $\mathrm{Sr}=$ Strontium $\mathrm{U}=$ Uranium 


\subsection{Basis for Use Restriction Modification}

The revised FALs for radionuclides other than Cs-137 as listed in Table 6-2 were established based on PALs presented in Section 2.2.1. The revised FAL for Cs-137 was established based on a site-specific RESRAD calculation of a $25 \mathrm{mrem} / \mathrm{yr}$ dose under an industrial scenario (see Section 2.2.2) as prescribed in Industrial Sites Project Establishment of Final Action Levels (NNSA/NSO, 2006c).

Therefore, no contaminants are present at this site in concentrations exceeding the revised FALs. All revised FALs other than Cs-137 were established at the PAL concentrations.

Table 6-2 presents the sample results that are the basis for the current UR and demonstrate that none exceed the revised FALs.

Table 6-2

Revised Final Action Levels for CAS 25-05-06

(Page 1 of 2)

\begin{tabular}{||c|c|c|c|c|c||}
\hline \multirow{2}{*}{$\begin{array}{c}\text { Sample } \\
\text { ID No. }\end{array}$} & $\begin{array}{c}\text { Depth } \\
\text { (ft bgs) }\end{array}$ & $\begin{array}{c}\text { Cs-137 } \\
\text { Revised FAL } \\
\mathbf{1 2 2} \mathbf{~ P C i / g}\end{array}$ & $\begin{array}{c}\text { Revised FAL } \\
\mathbf{1 4 3} \mathbf{~ p C i / g}\end{array}$ & $\begin{array}{c}\text { Revised FAL } \\
\mathbf{1 7 . 6} \mathbf{~ P C i / g}\end{array}$ & $\begin{array}{c}\text { Revised FAL } \\
\mathbf{8 3 8} \mathbf{~ p C i / g}\end{array}$ \\
\hline \hline EPR02B06 & $6.5-7.5$ & -- & -- & -- & $1.77 \pm 0.40$ \\
\hline EPR03B13 & $13.5-14.5$ & -- & -- & $0.08 \pm 0.030$ & -- \\
\hline EPR04A06 & $6-7$ & $44.5 \pm 5.7$ & $8.5 \pm 1.1$ & $0.42 \pm 0.081$ & $12.6 \pm 2.3$ \\
\hline EPR04A08 & $8.5-9.5$ & -- & $1.69 \pm 0.24$ & $0.108 \pm 0.034$ & -- \\
\hline EPR05A14 & $14-15$ & -- & -- & $0.08 \pm 0.03$ & -- \\
\hline EPR05A24 & $24-25$ & -- & -- & $0.093 \pm 0.035$ & -- \\
\hline EPR11A10 & $10-11$ & -- & -- & $0.085 \pm 0.031$ & -- \\
\hline EPR12A07 & $7.5-8.5$ & -- & -- & $0.102 \pm 0.035$ & -- \\
\hline EPR12A10 & $10-11$ & -- & -- & $0.109 \pm 0.039$ & $3.42 \pm 0.69$ \\
\hline EPR13A08 & $8-9$ & -- & $2.03 \pm 0.30$ & $0.112 \pm 0.036$ & $8.9 \pm 1.6$ \\
\hline EPR13A10 & $10.5-11.5$ & -- & -- & $0.083 \pm 0.030$ & $3.62 \pm 0.72$ \\
\hline EPR13A20 & $20.5-21.5$ & -- & -- & $0.104 \pm 0.034$ & -- \\
\hline EPR13A99 & $10.5-11.5$ & -- & -- & $0.101 \pm 0.033$ & $3.09 \pm 0.62$ \\
\hline EPR14A07 & $7.5-8.5$ & -- & $1.61 \pm 0.30$ & $0.115 \pm 0.052$ & $3.70 \pm 0.71$ \\
\hline EPR15A07 & $7.5-8.5$ & -- & -- & $0.084 \pm 0.039$ & $(\mathrm{~J})$ \\
\hline EPR16A07 & $7.5-8.5$ & -- & -- & $0.09 \pm 0.039(\mathrm{~J})$ & $2.63 \pm 0.53$ \\
\hline
\end{tabular}


Table 6-2

Revised Final Action Levels for CAS 25-05-06

(Page 2 of 2)

\begin{tabular}{|c|c|c|c|c|c|}
\hline \multirow{2}{*}{$\begin{array}{l}\text { Sample } \\
\text { ID }\end{array}$} & \multirow{2}{*}{$\begin{array}{l}\text { Depth } \\
\text { (ft bgs) }\end{array}$} & Cs-137 & U-234 & U-235 & Sr-90 \\
\hline & & $\begin{array}{l}\text { Revised FAL } \\
122 \mathrm{pCi} / \mathrm{g}\end{array}$ & $\begin{array}{c}\text { Revised FAL } \\
143 \text { pCi/g }\end{array}$ & $\begin{array}{c}\text { Revised FAL } \\
17.6 \mathrm{pCi} / \mathrm{g}\end{array}$ & $\begin{array}{c}\text { Revised FAL } \\
838 \mathrm{pCi} / \mathrm{g}\end{array}$ \\
\hline EPR17A07 & $7.5-8.5$ & $11.9 \pm 1.5$ & -- & -- & $4.82 \pm 0.92$ \\
\hline EPR17A10 & $10-11$ & -- & -- & $0.129 \pm 0.047$ & $3.03 \pm 0.61$ \\
\hline EPR18A07 & $7-8$ & -- & -- & $0.091 \pm 0.041$ & -- \\
\hline EPR18A09 & $9.5-10.5$ & -- & -- & $0.087 \pm 0.037$ & -- \\
\hline EPR19A07 & $7-8$ & -- & -- & $0.087 \pm 0.041$ & -- \\
\hline EPR19A09 & $9.5-10.5$ & -- & -- & $0.073 \pm 0.036$ & -- \\
\hline EPR19A15 & $15-16$ & -- & -- & $0.071 \pm 0.035$ & -- \\
\hline EPR20A10 & $10-11$ & -- & -- & $0.073 \pm 0.040$ & -- \\
\hline EPR21A09 & $9.5-10.5$ & -- & -- & $0.081 \pm 0.041$ & -- \\
\hline EPR22A09 & $9.5-10.5$ & -- & -- & $0.07 \pm 0.035$ & -- \\
\hline EPR29A20 & $20-21$ & -- & -- & $0.073 \pm 0.026$ & -- \\
\hline
\end{tabular}

bgs $=$ Below ground surface

$\mathrm{Cs}=$ Cesium

$\mathrm{FAL}=$ Final action level

$\mathrm{ft}=$ Foot

$\mathrm{J}=$ Estimated value

-- = No detects above original action levels

\subsection{Proposed Modification}

Remove the FFACO UR, associated fencing and postings, and inspection and maintenance requirements from this site.
$\mathrm{pCi} / \mathrm{g}=$ Picocuries per gram

$\mathrm{Sr}=$ Strontium

$\mathrm{U}=$ Uranium 


\section{References}

FFACO, see Federal Facility Agreement and Consent Order.

Federal Facility Agreement and Consent Order. 1996 (as amended). Agreed to by the State of Nevada; U.S. Department of Energy, Environmental Management; U.S. Department of Defense; and U.S. Department of Energy, Legacy Management.

NNSA/NSO, see U.S. Department of Energy, National Nuclear Security Administration Nevada Site Office.

NNSA/NV, see U.S. Department of Energy, National Nuclear Security Administration Nevada Operations Office.

U.S. Department of Energy, National Nuclear Security Administration Nevada Operations Office. 2001a. Corrective Action Decision Document for Corrective Action Unit 262: Area 25 Septic Systems and Underground Discharge Point, Nevada Test Site, Nevada, Rev. 1, DOE/NV--744-Rev 1. September. Las Vegas, NV

U.S. Department of Energy, National Nuclear Security Administration Nevada Site Office. 2003a. Closure Report for Corrective Action Unit 262: Area 25 Septic Systems and Underground Discharge Point, Nevada Test Site, Nevada, Rev. 1, DOE/NV--897-Rev 1. July. Las Vegas, NV.

U.S. Department of Energy, National Nuclear Security Administration Nevada Site Office. 2004f. NV/YMP Radiological Control Manual, DOE/NV--11718-079, Rev. 5. Prepared by Bechtel Nevada. Las Vegas, NV.

U.S. Department of Energy, National Nuclear Security Administration Nevada Site Office. 2006c. Industrial Sites Project Establishment of Final Action Levels, Rev. 0, DOE/NV--1107. Las Vegas, NV. 


\title{
Library Distribution List
}

\author{
$\underline{\text { Copies }}$ \\ U.S. Department of Energy \\ 1 (Uncontrolled, electronic copy) \\ National Nuclear Security Administration \\ Nevada Site Office \\ Technical Library \\ P.O. Box 98518, M/S 505 \\ Las Vegas, NV 89193-8518 \\ U.S. Department of Energy \\ 1 (Uncontrolled, electronic copy) \\ Office of Scientific and Technical Information \\ (Uncontrolled, electronic copy) \\ P.O. Box 62 \\ Oak Ridge, TN 37831-0062 \\ Southern Nevada Public Reading Facility \\ 2 (Uncontrolled, electronic copies) \\ c/o Nuclear Testing Archive \\ P.O. Box 98521, M/S 400 \\ Las Vegas, NV 89193-8521 \\ Manager, Northern Nevada FFACO \\ 1 (Uncontrolled, electronic copy) \\ Public Reading Facility \\ c/o Nevada State Library \& Archives \\ 100 N Stewart Street \\ Carson City, NV 89701-4285
}

